ARTICLE

\title{
Chile's New Constitution: What Right to Health?
}

\author{
Eduardo Arenas Catalán ${ }^{1}$ (D)
}

Accepted: 21 October 2021 / Published online: 2 November 2021

(C) The Author(s) 2021

\begin{abstract}
Chile is a country crossed by economic inequalities. The constitutional process has opened a space to problematize the institutions that reproduce these inequalities. This paper joins into this discussion arguing that a nuanced focus on the right of access to healthcare under international law would fit the future Constitution better. I label this focus 'nuanced', in reaction to international law's limited ability to address justice claims located at the core of Chile's social and constitutional discontent. I argue that the right to health under international law is unlikely to address the problem of unequal enjoyment of healthcare services. The paper argues that a better approach would be to integrate a solidaristic understanding to this human right. The added value of solidarity translates in a more substantive conceptualization of social rights where they become at the service of the liberty of all. Through a critical discussion about the inception of the right to health under Chile's current Constitution, the paper shows the limitations of today's understanding and the underlying reasons for the transformation it proposes.
\end{abstract}

Keywords Chile $\cdot$ Constitution of $1980 \cdot$ Right to health $\cdot$ Solidarity $\cdot$ Social rights

This contribution is an expansion of a previous work written in Spanish. See: Arenas Catalán (2021a) Derecho a la Salud en la Nueva Constitución Chilena: Libertad, Solidaridad e Instituciones. The author is grateful to Raúl Sánchez-Urribarri, Sergio Verdugo and an anonymous reviewer for their useful suggestions and critical remarks on previous versions of this work.

Eduardo Arenas Catalán

Eduardo.arenascatalan@ou.nl

1 Assistant Professor in International Law at the Department of Criminal, International and European Law, Faculty of Legal Sciences, Open University, Heerlen, The Netherlands 


\section{Introduction}

The most relevant effect of the social revolt that shook Chile in October of 2019, was the creation of conditions which led to the Parliamentary agreement one month afterwards. ${ }^{1}$ Pursuant to this agreement, citizens were called on a plebiscite to decide whether or not they would wish the drafting of a new Constitution. The vast majority of voters agreed, and tasked a Constitutional Convention with the responsibility. ${ }^{2}$

The inability to address economic disparities in the post-Pinochet Chile is one of the likely explanations for the discontent behind the social revolt. ${ }^{3}$ The way the right to the highest attainable standard of health has been promoted in Chile illustrates Chileans' negative perception of their political and constitutional system. ${ }^{4}$ In this piece, I focus exclusively on financial access to healthcare, meaning that my references to the right to health relate only to this specific dimension. What understanding of this human right could be useful to tackle Chile's structural socio-economic deficiencies, same which were deplored by the social revolt? This paper will argue that the right to health should be protected in ways different than in Chile's Constitution of 1980. By the same token, I show that Chile's problems with social rights are unlikely to be met if this human right is understood in line with official interpretations of the right to health, under international law. ${ }^{5}$ I also argue that the obstacles Chile has experimented in attempting to establish more robust social rights cannot be separated from the content and function the Constitution of 1980 played after the end of the dictatorship. The legitimacy of the Constituent process and the constitutional draft that will be proposed to the country require to understand this and, accordingly, overcome those limitations.

In contrast, this paper will argue that a solidaristic understanding of the right to health is more likely to meet the expectations deposited over Chile's Constitutional Convention. This solidaristic view has more in common with the way this human right was understood in the Post-War than with the way it has been officially interpreted in the last three decades by United Nations (UN) bodies. By virtue of their definition and function, social rights and the right to health in particular, play a role in the struggle against inequality. ${ }^{6}$ Amidst the significant increase of economic disparities in market-oriented liberal democracies, this attribute is of particular salience. Importantly, Ricardo García Manrique thinks that the operation of social

\footnotetext{
1 Senado de Chile (2019); Garcés (2020), p. 44.

2 Two questions were formulated to voters in the plebiscite of 25 October 2020. Firstly, whether they would wish a new Constitution being drafted and, in the affirmative, whether they would wish the new Constitution to be drafted by a Constitutional Convention or by a Mixed Constitutional Convention (the latter being comprised in equal parts both by members of Congress and elected representatives). The 'approval' option obtained $78.27 \%$, while the Constitutional Convention option obtained $78.99 \%$ of the votes. See Servicio Electoral de Chile (2020).

3 Alberto Mayol linked the discontent with a deep sensation of injustice grounded on an inability to tackle economic disparities and the falseness of the promise of social mobility. Mayol (2012), pp. $23,97$.

4 CIPER (2020); CIPER (2019).

5 For a more elaborated description of this interpretation, see Arenas Catalán (2021a), ch 2.

6 WHO (1978), para II.
} 
rights is one where commercial exchange should be completely excluded, as otherwise goods essential to liberty would not be at the reach of everyone in conditions of equality. ${ }^{7}$ Under our current setting, the most relevant role the right to health can play is to make liberty as real and effective for those who possess abundance of money, as much as for those who lack it. ${ }^{8}$

In the next section I will look at the official UN interpretation on the right to health. I will argue that despite a few advantageous elements, the laconic way with which this interpretation approaches public health services renders equal rights to all unlikely. Contrarily, taking my cue from the work of Fernando Atria, I consider institutions a pre-requisite for liberty and life in common. ${ }^{9}$ Institutions mediate making probable the improbable. ${ }^{10}$ In the case of the right to health, the improbable is equal enjoyment of healthcare. The function of the public health service institution is to turn that improbability into a probability. In the third section, I will present a critical discussion about the right to health in the context of Chile's Constitution of 1980. I shall argue that the limitations affecting the official UN interpretation are also present in Chile's Constitution but in an even more stringent way. Arguing that this latter view promotes a selective understanding of liberty, I will conclude that such a definition cannot be squared with the universalist premises of human rights law. In the fourth section, drawing on Chile's constitutional tradition before Pinochet, I will present a brief argument in favor of a solidaristic understanding of the right to health. I conclude that this perspective fits better the demands that have emerged from the endemic socio-economic disbalances Chile suffers from.

\section{The Human Right to Health: The Official UN Interpretation and the Institutional Challenge}

Just like what it is the case with other human rights, the ultimate function of social rights is to revert the problem of poorly distributed power. ${ }^{11}$ This is especially important in Chile, a country where social problems are not limited to poverty, but also concern significant economic disparities. ${ }^{12}$ As stated by one of the most authoritative right to health instruments, the Alma Ata Declaration recognizes the struggle against inequality as a constitutive element of the right to health. ${ }^{13}$

\footnotetext{
7 García Manrique (2013), pp. 18-21, 241, 265, 269-270.

8 This is in line with Gerald Cohen's observation that in a market society 'money and its lack, imply relations of freedom and unfreedom' and that the protest against poverty is a plea 'against the extreme unfreedom of the poor in a capitalist society, and in favour of a much more equal distribution of freedom'. Cohen and Otsuka (2011), pp. 184-86.

9 Atria (2016), p. 20.

10 Atria (2016), p. 154.

11 Garcia Manrique (2013), p. 34.

12 Chile is the most unequal country in the OECD (Oxfam International 2014, p. 190) and is positioned among the top 10 most unequal countries in the world (World Bank 2016, p. 11).

13 WHO (1978), para II.
} 
In spite of this important emphasis, the use of social rights as a tool against economic disparities is a pending task. This is especially the case in Chile, a country where economic disparities mirror a public and private divide in the area of healthcare services. The fragmentation of these services in Chile pairs the economic status of the household. ${ }^{14}$ In a country where $64 \%$ of workers earns less than $€ 430,{ }^{15}$ social stratification is reinforced by the fact that the wealthiest groups rely on private healthcare services while a $76 \%$ majority does it on State run healthcare services. ${ }^{16}$ This public and private divide can be characterized by a lower quality and quantity of healthcare services for the population ascribed to the public sector. The division illustrates the perception of injustice which arguably led to the 2019 October revolt.

Critically, the struggle against economic disparities is only to a limited extent in conflict with the official UN human rights law interpretation. The closest this discipline addresses this problem is the so-called affordability of goods and healthcare services. ${ }^{17}$ This affordability forms part of an all-encompassing concept of accessibility. This latter concept is in turn part of an even more comprehensive framework that includes: availability, acceptability and quality. Together, these elements structure the core of the UN interpretation of the right to health under international law. ${ }^{18}$

As the concept makes clear, affordability demands services to be payable by everyone. The universality of human rights law is, in principle, expressed in this conceptualization. However, looking closer, this universality translates in access to healthcare services 'to those who do not have sufficient means'. ${ }^{19}$ The United Nations Committee on Economic, Social and Cultural Rights (hereafter, the UNCESCR Committee) has seconded this perspective when reviewing the periodic reports of progress submitted by the State Parties of the International Covenant on Economic, Social and Cultural Rights. From these assessments it has become clear that healthcare services need to be especially provided without discrimination to vulnerable groups and otherwise disadvantaged populations. ${ }^{20}$ As per the content of the right to health, the only services that appear to be mandatorily provided are those relating to essential primary healthcare. ${ }^{21}$

\footnotetext{
${ }^{14}$ According to PAHO, Chile's health system is fragmented regarding the financing, guarantee, provision of services and unequal availability of resources to serve a population that depends from each sector. Out of pocket payments are $38 \%$ of total health expenditures in health and that affects mainly families of lesser resources (author's translation). Organización Panamericana de la Salud and Organización Mundial de la Salud (2017), p. 110; Facultad de Derecho Universidad Diego Portales (2003), p. 383.

15 The amount mentioned is a rough equivalence of the $\$ 400,000$ Chilean pesos these workers earn per month. Durán and Kremerman (2020), p. 8.

${ }^{16}$ Organización Panamericana de la Salud and Organización Mundial de la Salud (2017), p. 109.

${ }^{17}$ UNCESCR (2000), para $12 \mathrm{~b}$.

${ }^{18}$ UNCESCR (2000), para $12 \mathrm{~b}$.

19 UNCESCR (2000), para 19.

${ }^{20}$ See the UNCESCR Committee's remarks regarding Roma populations (UNCESCR 2008, para 48; see also UNCESCR 2016, para 47) or indigenous populations (UNCESCR 2014b, para 22) among many other similar examples.

${ }^{21}$ UNCESCR (2000), para 43. See also UNCESCR (2014a), para 19; UNCESCR (2015), para 31; UNCESCR (2010), para 27.
} 
This approach offers two advantages. For a start, its operationalization is quite clear-cut. The discharging of human rights obligations by the State translates in making essential treatments to individuals at a disadvantage affordable. States, therefore, need not to incur in institutional evaluations. As long as basic services to those in dire straits are granted, human rights obligations can be said to be complied with no matter the institutional form of healthcare services. Moreover, because a minimum focus is more likely to be compatible with varied politico-institutional settings, this focus is more flexible than a stringent approach. From the point of view of international human rights law instruments this is most probably an advantage as States could be incentivized to ratify the Covenant. Such an approach was consolidated in 2000 by means of a specific legal framework for the right to health: General Comment 14 expressed the continuous application of human rights obligations irrespective of the setting within which these services were granted: public, private or mixed. ${ }^{22}$

Despite these advantages, a number of elements are problematic about this interpretation. Granting healthcare services equally to all, tackling economic inequalities, fostering social cohesion and making efficient use of scarce collective resources-all critical elements from the point of view of Chile's present conjuncture - are all highly dependent on the chosen institutional setting. That General Comment 14 categorizes both commercial and public services in the same way from the point of view of its potential to be either human rights compliant or threatening, far from a supposed neutrality or middle ground, uncovers the neoliberal features of this interpretation. Seeking to provide an equal and universal distribution by means of an inherently unequal mechanism as the market can only be grounded in an ideological conviction. ${ }^{23}$ Having withdrawn from a focus around universal production and distribution of health goods and services, the right to health focuses on the provision of minimums. ${ }^{24}$ As a result, this legal framework places individuals' asymmetrical enjoyment of healthcare services beyond human rights review. Having said this, in recent reviews, the UNCESCR Committee has at times shifted from this approach and engaged in a focus on universality around a more solidaristic focus. ${ }^{25}$ Whether this perspective will replace the way the human right to health has been up to this point predominantly interpreted, ${ }^{26}$ remains to be seen.

Despite its authority, the UN interpretation is simply one among others. ${ }^{27} \mathrm{~A}$ classical 1984 decision from Portugal's Constitutional Court deserves highlight.

\footnotetext{
22 UNCESCR (2000), para 36.

23 Arenas Catalán (2021a, b) ch 4, s 3.2.2.

24 UNCESCR (1990), para 10; UNCESCR (2000), paras 43, 47; on a report on Uzbekistan, the UNCESCR Committee expressed concern over 'the transition from a free to a prepaid health system and the introduction of private insurance-based medical care'. Yet, those dynamics were worthy of note insofar they could 'impact negatively on low-income groups and the rural population'. See UNCESCR (2006), para 29.

25 In some recent observations on South Africa, the UNCESCR Committee addressed 'the large disparities between the public and private health-care systems, with the public system at a disadvantage in relation to the number of medical professionals, medical equipment and medical expenditure...' UNCESCR (2018), para 63.

26 For a description of this interpretation see Arenas Catalán (2021a), ch 2.

27 Arenas Catalán (2021a, b), p. 5.
} 
Responding to an attempt of the government to eliminate by fiat a significant part of the progressive national healthcare system previously created by law, the Tribunal interpreted that the National Health Service was a constitutive element of the right to health and its first means of realization. ${ }^{28}$ The Court ruled that this service could not be eliminated unless the right to health was also eliminated, something which in turn required a constitutional amendment. ${ }^{29}$ In sum: eliminating the National Health Service did not seem to the Constitutional Court something very different from eliminating the right to health.

It is interesting to observe how this solidaristic understanding of the right to health is in no way foreign to the constitutional tradition Chile was headed, prior to the 1973 coup. Chile was in fact developing institutions with an inclination towards universal social protection. This was indeed the case with regard to the institution of the National Health Service (Servicio Nacional de Salud, SNS). The constitutional norm that enabled this institutional practice is valuable in a comparative perspective. Chile's Constitution of 1925 was the first one in the world to enshrine a constitutional norm dedicated to the protection of health. ${ }^{30}$ It is a provision two decades older than the 1948 Universal Declaration of Human Rights which among its list of social security rights, included 'medical care'. ${ }^{31}$ The provision is also older than the preamble of the 1946 Constitution of the World Health Organization (WHO), which became well-known due to the influence it exerted on what would become the most authoritative legal norm on the right to health: Article 12 of the 1966 International Covenant on Economic, Social and Cultural Rights. ${ }^{32}$

The fourth paragraph of Article 10.14 of Chile's Constitution of 1925 stated:

'it is a duty of the State to safeguard public health and the hygienic welfare of the country. Every year, a sufficient amount of money must become available to sustain a national salubriousness service' (author's translation). ${ }^{33}$

Although a set of healthcare services realized this constitutional provision, the most significant step was the coming into being of Chile's SNS, created in 1952 by Law 10,383, and in force until 1979, when under the government of the military junta, an entire different structure was enacted. ${ }^{34}$ Chile's SNS was based on ideas drafted by Salvador Allende Gossens ${ }^{35}$ who, before becoming President in 1970, had served as Health Minister in the late 1930s and early 1940s. Chile's SNS was created four years after the British National Health Service, and it originally

\footnotetext{
28 Tribunal Constitucional Portugal (1984), para (2)(3)(1).

29 Tribunal Constitucional Portugal (1984), para (2)(3)(3).

30 Byrne (2009), p. 526.

31 UNGA (1948), art 25.1.

32 UNGA (1966), art 12.

33 Constitución Política de la República de Chile (1925), art 10.14. This provision was amended in 1971 modifying the word 'salubriousness' by 'health'. Ley de Reforma Constitucional N 17,398 (1971).

34 Biblioteca del Congreso Nacional de Chile, p. 52.

35 A fundamental antecedent of the SNS was the legal project of 10 June 1941, see: Urriola Urbina et al. (2009), p. 75.
} 
envisaged the single-tiered structure and universalist approach that characterized the British NHS. ${ }^{36}$ Although the universalist and single-tiered structure of the SNS was moderated by opposed political groups, the SNS contributed to make the structure of healthcare services more effective and less fragmented. ${ }^{37}$

\section{The Right to Health in the Constitution of 1980}

I shall now look at the right to health from the perspective of the way this human right has been protected under the Constitution of 1980, currently in force. My research interest is to critically assess the legal technique and effects promoted by the Constitution's conceptualization of liberty. Article 19 number 9 states:

Article 19. The Constitution guarantees all persons:

9. The right to health protection.

The State protects the free and equal access to actions for the promotion, protection and recovery of health and for the rehabilitation of the individual.

It will also be responsible for the coordination and control of the health-related actions.

It is a preferential duty of the State to ensure the implementation of healthrelated actions, whether provided through public or private institutions, in the form and conditions prescribed by law, which may establish compulsory contributions.

Every person shall have the right to choose the health care system that he wishes to join, be it State-owned or private. ${ }^{38}$

(a) Social rights related duties under the Constitution of 1980

While Article 19.9 does not make any reference to a national or public health service, the ruling of the Portuguese Constitutional Court not only considers it a constitutive element of the right to health, but the primary means of its realization. Why so much difference?

It is fair to say that the ontological priority of Article 19.9 is placed, to put it in a commercial language, on the demand rather than on the supply. ${ }^{39}$ The Constitution speaks of 'health actions', as if the characteristics of the body in charge of executing those actions would be of less relevance. In fact, that is accurate to describe what was had in mind. Admittedly, the 'preferential' duty with which these actions were backed was one of special, reinforced nature. By virtue of

\footnotetext{
36 Sánchez Bustos (2013), pp. 227-228.

37 Sánchez Bustos (2013), pp. 227-228; Urriola Urbina and others 2009, p. 73.

38 Constitución Política de la República de Chile 1980, art 19.

39 Answering to an intervention of the then Minister of Health, General Fernando Matthei, the Presidente of the Constituent Commission, Enrique Ortúzar, stated: '...regarding what could be a national health system it seems that in the opinion of the Minister and of the other attendees, its consecration in the constitutional text would not be necessary' (author's translation). Ortúzar, Session 1901976.
} 
this duty, the State could not discontinue the execution of those actions. ${ }^{40}$ Yet, the fact that the State's duty could be pursued through public or private institutions left a question open: can there be a duty in the context of fundamental rights when that which is being instituted - the private initiative in the area of healthcare-is something which by its nature generates correlative rights only to the minority able to pay for them?

In this respect, Constanza Salgado and Tomás Jordán have shown how Chile's Constitutional Tribunal and regular courts of law have interpreted this duty in ways where private health payers, so called ISAPREs, would not be merely private entities, but would be in an intermediary position closer to the public realm. They would offer 'benefits to satisfy needs of general interest'. ${ }^{41}$ The unilateral rise in healthcare plans, interpreted in multiple writs of protection (recursos de protección) as 'arbitrary', would be a consequence of this special regime. This regime would be under a greater responsibility threshold than the private one. While Salgado acknowledges the inherent difficulty of guaranteeing a right which can be made conditional to ability to pay and from which private agents can profit from, ${ }^{42}$ she argues in favor of the public function that would have been given to the ISAPREs. This is based, inter-alia, in the lex-specialis character of Article 19.9, in contrast with what would be the more general character of the right to embark in an economic activity, enshrined in Article 19.21. ${ }^{43}$ Be that as it may, this view must still clarify in what way private healthcare services, despite their commercial distribution pattern, could fulfil a duty everyone must be in the position to benefit from.

The reason why this sui generis duty was established is more likely to be found in the intent of the drafters of the 1980 Constitution. Avoiding a wording that could even suggest state monopoly, the State duty to guarantee healthcare services is phrased in a way compatible with the commercial provision of healthcare. I therefore doubt about the accuracy of the view according to which the Constitution of 1980 would have considered the action of private parties one with the characteristics of a public service. Such a view is not backed by the travaux préparatoires of the Constituent Commission. What was in fact searched was to ensure an action of private parties in ways that would not exclude their commercial nature. The specific discussion on the expression 'preferential', shows Jaime Guzmán insisting in that word against the proposal of Alejandro Silva Bascuñán, who sought to exchange it for the word 'necessary'. According to Guzmán, the expression preferential entailed a 'value judgment which enabled the State to act when an efficacious action from private parties would be lacking'. ${ }^{44}$ This makes clear that the term preferential is another further confirma-

40 Tribunal Constitucional de Chile (2010), pp. 104-105.

41 Salgado (2015), p. 423. For a detailed exam of that case law see Jordán (2013).

42 Salgado (2015), p. 425.

43 Constitución Política de la República de Chile (1980), art 19.21.

44 Guzmán, Session 205 (1976) (author's translation). 
tion of the subsidiary nature of State action, and by no means, a description of a public motivation regarding the commercial initiative in the area of healthcare and, certainly not, a proscription of the commercial interest of private parties in this field.

What concept of liberty is promoted by such an understanding about the scope of social rights? In the next section I shall reflect on this question.

(b) The liberty of social rights under the Constitution of 1980.

It is beyond contestation that the ideas of Jaime Guzmán were influential in the commission that drafted the Constitution of 1980. This was also the case regarding the connection between social rights and liberty. For Guzmán:

'It is evident that, to the extent the State verifies that the private initiative satisfactorily grows in the field of healthcare, the State will subsequently restrict its own action in this field given that it involves a burden to the public budget...,45

Moreover, the "private initiative is the basis and [...] the subsidiary is the State, even if the subsidy covers most of the healthcare offered in the country'. ${ }^{46}$

Basing myself in one of the hypothesis of The Other Model, ${ }^{47}$ Guzmán's perspective can be understood as an expression of the neoliberal utopia. According to this vision, the market would naturally fulfil the needs of everyone with an efficiency unheard of. After forty years, the people in the streets identified the Constitution of 1980 as a leading cause for Chile's development malfunctioning. What to say, in this time of balances, about the persistent $76 \%$ of the population which remains ascribed to the public health payer system, FONASA ${ }^{48}$ I would suggest three considerations. Firstly, that this figure reflects a critical aspect highlighted in the ruling of Portugal's Constitutional Court, abovementioned: without a public healthcare service, the right to health becomes illusory. ${ }^{49}$ Secondly, that an efficient market, in the sense of selfsufficient, accessible to the majority and widely supported, did not take place. ${ }^{50}$ But even if Chile was on track of accomplishing such a promise-in all fairness Guzmán acknowledged that that 'might take a long time" ${ }^{51}$ - people in Chile are unwilling to

\footnotetext{
$\overline{45}$ Guzmán, Session 192 (1976) (author's translation).

46 Guzmán, Session 192 (1976) (author's translation).

47 Atria et al. (2014), pp. 50-51.

48 Organización Panamericana de la Salud and Organización Mundial de la Salud (2017), p. 109.

49 According to figures of the WHO, in 2016 Chile's private health expenditures reached 997,8 PPA per capita. According to figures of the same agency during the same year, 17 countries incurred in a lower private health expenditure per capita obtaining, at the same time, a lower health expectation at birth time: Costa Rica, Slovenia, Greece, Denmark, the United Kingdom, Finland, Portugal, Ireland, New Zeland, Israel, Sweden, Luxemburg, Island, Norway, Italy, Spain, Japan. See: WHO 2016a, b.

50 Mayol (2012), p. 24.

51 Guzmán, Session 190 (1976) (author's translation).
} 
remain waiting for its eventual coming true. Reality, which in Guzmán's interpretation appeared as an accident of relative value, ${ }^{52}$ reflects that Guzmán overestimated the capacities of the market in the field of healthcare.

The interpretation that Guzmán makes of subsidiarity does not match the political and constitutional tradition of Chile. ${ }^{53}$ Most importantly, it is useless, because even if it incentivizes the reality it seeks to develop (something which in the light of the $76 \%$ ascribed to the public sector is very hard to defend), this happens in exchange of an instability that threatens the rule of law.

How does Guzmán's concept of subsidiarity justifies the connection between liberty and social rights? Certainly, it was not an argument in favor of equal liberty. What was done was the exact opposite. The privileges of a minority were dressed up with the clothing of an undisputed principle as it is liberty. This served two goals. The first one, of smaller salience, was the liberty of choosing a physician, a cherished protection in the struggle of medical physicians against the 'former regime' (Allende's government). ${ }^{54}$

The second one, of more significance, is Guzmán's assertion about the need to expressly guarantee 'the right of private initiative in the area of healthcare' ${ }^{55}$ In agreeing with this proposal, the drafters of the 1980 Constitution blocked the objectives of equal liberty and solidarity. The protected liberties were those of the few, not those of the many. Guzmán insisted that the scope of market action should be circumscribed by subsidiarity. Comparing healthcare with education, Guzmán indicated that: 'a group of parents may perfectly give life to a paid primary education establishment; and doing so could not be considered unconstitutional because it is not obligatory for these bodies to provide it free of charge.' ${ }^{56}$ Sergio Diez, in turn, indicated that: "what is normal in healthcare is liberty... and nobody can discuss, consequently, the existence of liberty to choose the medical system, and even, the specific place where a person wishes to obtain healthcare, in case a person chooses to be treated by the private system... ${ }^{57}$ The scheme became complete with a short but telling characterization of the limited prerogatives of the patient ascribed to the

\footnotetext{
52 In the constitutional discussion regarding social security, Guzmán stated that if due to lack of interest of private parties, the State [would have] all social security in its hands, that does not mean that such a system does not remain to be subsidiary. By the same token, it is still subsidiary the action of the State by virtue of which the State owns all schools or all healthcare provision if, in reality, the motivation of that action is the deficiency of private parties to adopt it, their impossibility, lack of interest or incapacity to do so' (author's translation). Guzmán, Session 205 (1976).

53 Cristi and Ruiz-Tagle (2006), p. 332.

54 Guzmán, Session 190 (1976) (author's translation).

55 Guzmán, Session 192 (1976) (author's translation).

56 Guzmán, Session 190 (1976); See also the intervention of Julio Pizzi, then Dean of the Faculty of Medicine at Universidad de Chile, who stated: 'regarding the free-of-charge character of healthcare... he finds it small that such a concept enters into such a broad constitutional provision' (author's translation); Ernesto Medina, then President of Chile's Medical Association was quoted in the following terms: 'regarding how you carry it out [the guarantee of healthcare], under what conditions you do it, whether you grant it freely... [he] thinks that that is secondary' (author's translation). Pizzi and Medina, Session 190 (1976).

57 Diez, Session 192 (1976) (author's translation).
} 
public sector, where: ' ...one should not exaggerate. If someone wishes to go to the State run system, one cannot elect the physician freely. ${ }^{58}$

It is relevant to note the way the constitutional rule is drafted. Free choice of provider and healthcare system are presented as if what would be at stake would be as unimportant as the choice between a Coke and a Pepsi ("whether provided through public or private institutions', 'be it State-owned or private'). The difference is that whereas these two products provide a more or less similar satisfaction and cost more or less the same, the care offered by the commercial clinicas of the Eastern side of the capital is qualitatively and quantitatively superior to the much cheaper or freeof-charge consultorios and hospitales distributed all over the country. ${ }^{59}$ When the protected good is nothing least than someone's life or physical integrity, these differences are no doubt important.

In the light of the abovementioned, what is the specific function of the Constitution's freedom of choice? There are at least two important elements. On the one hand freedom of choice entails a limit to the democratic legislator. The amendment of any element of this provision, including the dissolvement of the for-profit provision of healthcare, requires a Congress super-majority of two-thirds. ${ }^{60}$ On the other hand, freedom of choice is a prerogative of the privileged. It is thanks to this provision that those with greater resources can buy their way out of the waiting lists, slender options and scarcities characterizing these public services. The deceptiveness of this language emerges from presenting as pro-rights what in fact is a privilege for the few. Most fundamentally, injustice emerges from integrating the by definition unequal distribution of the market in an area where what should dominate is universal access. While this provision has contributed to make Chile's healthcare more commercial, it has also contributed to clarify what is lost when this right is not protected as a human right, but as the mere 'social claim' with which Jaime Guzmán actually identified it. ${ }^{61}$

This limited definition of liberty is aligned with the healthcare system introduced by the military junta. The National System of Health Services (Sistema Nacional de Servicios de Salud) is a mixed system with several tiers. There is first the 'institutional modality' with its four levels of contribution dependent on the resources of the household. ${ }^{62}$ There is then the 'free-election modality', which is conditioned to greater co-payments and, finally, the private healthcare sector handled by the ISAPREs. In this level the market operates with greater liberty. ${ }^{63}$ It is important not to forget the astounding exception of the Armed and Security Forces. Under the regulation of law 19,465 of 1996 and Decree Law 844 of 1975, the Armed and Security Forces are true institutional bubbles of solidarity. ${ }^{64}$ Esping Andersen, commenting

\footnotetext{
58 Diez, Session 192 (1976) (author's translation).

59 Aravena and Inostroza (2015), pp. 244-245.

60 Constitución Política de la República de Chile 1980, art 127.

61 Guzmán, Session 190 (1976) (author's translation).

62 Ministerio de Salud (2005), arts 159-161.

63 Ministerio de Salud (2005), arts 171-180.

64 Ministerio de Defensa Nacional (1975); Ministerio de Defensa Nacional (1996).
} 
on comparable cases, understands these exceptions as a means to attract the loyalty of groups within the population. ${ }^{65}$ I think that rather than depriving the Armed and Security Forces of the dignified treatment they have so far received, the logic thing would be to extend those schemes to the rest of the population.

Supposedly universal choices which are theoretically conditional and in practice unreachable but to a few, are not expressions of liberty. They are constitutional devices destined to entrench privilege. This false choice has discredited Chile's constitutional democracy. It represents a deviation from the precarious but still universalist path under which Chile's healthcare services were headed up to September 11, 1973.

In the next sub-section, I will focus on a recent contribution from Rosalind Dixon and Sergio Verdugo. ${ }^{66}$ For reasons of space, I cannot focus on the way these authors conceive the role social rights should play in the new Constitution. Yet, I would like to provide a critical reflection about the way these scholars have understood Chile's legal and political dynamics and how such a view impacts what is at stake with the right to health. This will allow me to take a critical stand regarding the suggestion, implicit in their work, that the main challenge for the constituent process necessitates more of a sound legislative and constitutional technique rather than a political willingness to confront the authoritarian nature and political ideals that permeate the Constitution of 1980 .

(iii) Reforms within the Constitution of 1980: the borders of permissibility.

Rosalind Dixon and Sergio Verdugo have suggested that the limited scope of social rights in Chile owe largely to 'the burdens of inertia' in the protection of social and economic rights. ${ }^{67}$ In line with this diagnosis, these scholars move on to propose a complex combination of various forms of institutional restraint and initiatives from State powers together with a set of public policies that would better protect social rights under what would be the future Constitution. In my view, this perspective downplays the legal and factual normative power the Constitution of 1980 has had since the end of the dictatorship. This is problematic for an assessment of the right to health in the Post-Pinochet Chile. Placing the emphasis on reform, as these authors do, distracts from the great achievement the Constitution of 1980 has had for its supporters all along these years: the way in which it has effectively outcasted from Chile's legal order the possibility, even the mere idea, of restoring a universal public healthcare service.

Dixon and Verdugo suggest that the space left for reform under the purview of the Constitution of 1980 was wide. They exemplify this pointing out a number of reforms or adaptations that have taken place, eg, the introduction of the AUGEGES Programme, the increasing of public spending on the healthcare system or the decisions of the Constitutional Tribunal which limited ISAPREs ability to increase

\footnotetext{
65 Esping Andersen (1990), p. 24.

66 Dixon and Verdugo (2021).

67 Dixon and Verdugo (2021), p. 36.
} 
prime prices to patients that posed greater financial risk. ${ }^{68}$ Although it is true that these changes occurred under the current constitutional framework, the key inquiry to determine the grip of the Constitution of 1980 over processes of reform lies in determining the areas that have historically been beyond the reach of Chile's electoral majorities. While Dixon and Verdugo are right to say that some aspects of the system could be reformed by simple majority, ${ }^{69}$ as it was mentioned earlier, the elimination of the commercial delivery of healthcare which consolidates an inequitable two-tiered healthcare model, can only be reformed through a two thirds supermajority in both houses of Congress. ${ }^{70}$ And even regarding those other elements of the health system that could be modified through simple majority, one should not forget that those 'majorities' have been generated under the rules of the notorious 'binominal' system instituted by Organic Law 18,700. ${ }^{71}$ This legal instrument can only be amended by a supermajority of four sevenths (and after 2005, three fifths) in both houses of Congress. All along its existence, this electoral system has been criticized by the way in which it has historically contributed to overrepresent the political right, perpetuating the legacy of the dictatorship. ${ }^{72}$ The electoral system was reformed only in 2015 , being substituted by a proportional system. ${ }^{73}$ However, one cannot underestimate the effects that this and other authoritarian enclaves have imprinted over Chile's political culture ideologically, in terms of representation and democratic participation. ${ }^{74}$ This is sufficiently documented and the only thing I would like to highlight at this point, is the subjective effect that these countermajoritarian institutions generated in Chilean politics: the positive knowledge that even when a reform could be carried out, it would have to adapt, in no insignificant measure, to the more general constitutional framework. This perspective seems corroborated by the fact that the constituent plebiscite of October 2020 - the one electoral act in thirty years of democracy with the potential of breaking out free from these limitations - was met with the greatest turn out in Chile's electoral history. ${ }^{75}$

Consequently, I find it problematic to attempt to explain the deficiencies in the provision of social rights in Chile by reference to the burdens of inertia, a phenomenon which in my view seems like an obstacle affecting liberal democracies more generally. The expression inertia suggests a negligent passivity that leads to the omission of Parliamentarian's duties. Yet, the label underplays or does not account for the decidedly antimajoritarian nature of the institutions and dynamics that characterized the Post-Pinochet years under the purview of the Constitution of 1980. Without denying that this notion could have some explanatory value, Chile's legislative inability to reform cannot be explained by refence to a general lethargy while at the same time failing to give enough credit to the ideological overlap between the political right and the authoritarian enclaves, together with a political technocratic

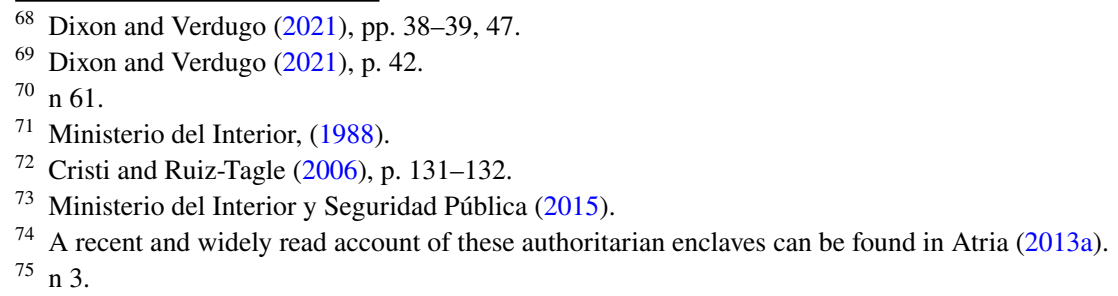


culture which resulted from a reasonable perception of what was and was not possible within the framework of the Constitution of 1980.

What one must do is to ask: what, in the last thirty years, was of political salience in the field of healthcare but which due to the institutional obstacles inherited from the Constitution of 1980 was placed beyond the reach of the majority? The unsurprising answer is the return to the universalist path Chile was headed prior to the 1973 coup in the shape of a single-tiered universal public healthcare service. This helps to understand why, in the vocabulary of Chile's scholars, a 'really significant' transformation had taken place when the Constitutional Tribunal engaged in the very modest declaration of unconstitutionality of the rule according to which ISAPREs were allowed to charge more money for primes regarding patients that posed greater financial risk. ${ }^{76}$ Political alternatives were thus restricted. More structural reforms such as annulling or severely limiting the for-profit provision of healthcare were out of the scope of the available legal options. As such, they were factually banned for thirty years from the political debate no matter the degree of interest they conceited. That some scholars do not see a future for the establishment of a singletiered healthcare system due to lack of consensus, ${ }^{77}$ so seems to me, is a conclusion that remains somewhat hooked to the sphere of possibilities determined by the oppressive boundaries of the Constitution of 1980.

After the 2019 social revolt, the horizons of Chile's political imagination have been considerably broadened. Whether the Constitutional Convention will discuss or establish a single-tiered universal healthcare service that heavily minimizes the role of the private sector is a possibility that can no longer be so easily discarded. Dixon and Verdugo are right to say that the constituent process has generated expectations, but it is paradoxical to worry about unfulfilled expectations while at the same time proposing an overcomplex constitutional approach paired with suggestions for moderate reform. In order to meet those legitimate expectations, but also to counter the likely threats that could feed from a too moderate outcome, ${ }^{78}$ the right to health should be enshrined as an entitlement associated to citizenship and medical need in the form of a universal public service. The particulars of this option are addressed in the next section.

\section{Reconstructing Chile's Constitutional Tradition: Solidarity}

As shown in Sect. 2, the official international perspective on the right to health contains similarities with Chile's current legal order. Just like Article 19.9, General Comment 14 of the UNCESCR Committee understand the human rights question as one disconnected from the setting in which healthcare services are provided. ${ }^{79}$ Moreover, the selective protection Chile gives to vulnerable

\footnotetext{
76 Bassa Mercado and Aste Leiva (2015), p. 233

77 Bossert and Villalobos Dintrans (2020), p. 5.

78 Bossert and Villalobos Dintrans (2020), p. 7.

79 n 23.
} 
individuals ${ }^{80}$ is in line with the international human rights framework which revolves around minimum 'core' obligations and special protection to individuals in a position of disadvantage. ${ }^{81}$

For these reasons, drafting a right to health provision that would mainly import the emphases of international law is an approach unlikely to meet Chile's structural deficiencies in this field. This is particularly true after the 2019 social revolt. Despite Chile's significant steps forward, ${ }^{82}$ the revolt highlighted the unaddressed lack of equity of the health policies implemented since the return of democracy. ${ }^{83}$ Chile craves for social justice and the human rights that will give shape to the new Bill of Rights must be able to channel it.

A solidaristic interpretation of the right to health conceives this human right without losing grip from social justice. From the point of view of solidarity, the right to health entails both a material and an immaterial dimension. The material dimension makes reference to the health facilities, goods, services and conditions involved in the operation of healthcare. ${ }^{84}$ The immaterial dimension involves the operationalization of the 'equality of status' once identified by $\mathrm{TH}$ Marshall as the function of social rights. ${ }^{85}$ Achieving this equality of status is not something that can be reached by granting vital means-tested entitlements associated to criterions of vulnerability. Such an understanding of equality is intrinsically connected to the individuals in need of equalization. But these individuals are not equalized. Neither practically nor theoretically. As the practice in Chile demonstrates, the entitlements generated by the public system are of far lower intensity than those to which individuals in the position to pay for their healthcare can receive. Moreover, a pre-determined minimum dignity threshold is by definition different to the entitlement individuals in the position of purchasing healthcare services can obtain. For this reason, the question of equality of status is one which should not be centered on individuals, but on institutions.

Up to this point the predominant interpretation of Article 12 of the International Covenant on Economic, Social and Cultural Rights has been centered on minimum entitlements to the disadvantaged, leaving the provision of healthcare mainly open. Against the way Article 12 has been interpreted by the UNCESCR Committee, this provision demands granting the highest attainable standard of health equally to everyone. ${ }^{86}$ This requires to clarify the principles and institutions that can render this promise probable. To this end, the identification of the duty bearer together with

\footnotetext{
$\overline{80}$ Ministerio de Salud (2005), art 147.

81 n 21.

82 Since 2005, the AUGE-GES Programme established a covered minimum floor to a determined number of diseases and pathologies. These treatments are covered free of charge with independence of the system to which the individual is ascribed. Superintendencia de Salud.

83 Atria (2013b), pp. 35-42; Pereyra González (2019).

84 UNCESCR (2000), para 9.

85 Marshall (1950), p. 56.

${ }^{86}$ Realizing the highest attainable standard of health 'can be understood to be reflected by the standard of health enjoyed by the most socially advantaged group within a society'. Braveman and Gruskin (2003), p. 254.
} 
the identification of solidaristic principles of distribution must be made explicit. A solidaristic understanding of the right to health in Chile involves two components: (a) the identification of a public health institution as the main duty bearer of the human right to health, and (b) the gradual, precarious and everlasting effort to decommodify healthcare services and, in a proportionally inverse manner, the gradual, precarious and everlasting effort to socialize the provision of those services. ${ }^{87}$

In Chile, the solidaristic path to fulfil the right to health leads towards the revival of the SNS, as envisioned in Article 10.14 of Chile's Constitution of 1925 (including the reform of 1971). This provision presents the right to health from the point of view of the institutions in charge of fulfilling the duty. This is logical. An insufficient characterization of the duty to protect health would lead, in a inversely proportional way, to an insufficient correlative right. A limitation is that the constitutional provision does not enter into detail on the principles and form of accomplishing such a task. Following the experience of the British NHS which, as already indicated, was an inspiration for Chile's SNS, Chile's SNS fundamental principles of operation and distribution should also be constitutionalized. ${ }^{88}$ By revolving around citizenship and medical need, these principles are not means tested for which reason they do not require an individual characterization of the recipients. As such, these principles of distribution offer a path to approach the goal of equal liberty.

\section{Conclusion}

The constitutional provision on the right to health of the Constitution of 1980 seeks and is successful at generating a prerogative designed exclusively for the privileged. This 'freedom of choice' does not reflect a liberty in line with the social and democratic rule of law I think Chileans are attempting to construct. In Chile, admittedly, the preferential duty of the State leads to the assistance for indigents under the institutional modality and the protection floors created by the AUGE-GES programme. Even though these efforts are worthwhile, they have been compatible with the generation of institutional parallelisms where the experience of obtaining healthcare is diametrically different for the rich and the poor, with negative consequences for the legitimacy of Chile's constitutional democracy. The discussion I have been promoting has been another one. It aims at answering what can we do to avoid the normalization of institutions of first, second and third category. What has motivated me has

\footnotetext{
87 This view is grounded on a number of elements. From the legal theory point of view, I take my cue from the work of Fernando Atria. The first element emerges from his idea of 'political institutions' which in turn is based on 'the socialist notion of reciprocal duty'. The second element is associated with Atria's consideration of social rights as 'anomalous grafts'. See Atria (2015), pp. 602, 606, 611; for the second element see: García Manrique (2013), pp. 240-241. From the point of view of the human right to health, this perspective is linked to the Alma Ata Declaration, which considers that primary healthcare: (a) is 'central' to the health system of a nation, (b) should be 'made universally accessible', and (c) should be considered 'the first element of a continuing health care process'. WHO (1978), para VI.

88 Atria recounts them as follows: (a) concern to the needs of all; (b) provision free of charge at the point of delivery, and (c) distribution on the basis of need rather than on ability to pay. Atria 2014 p. 248.
} 
been the attempt of relating the right to health to institutions able to nurture everyone by their status of human, in place of having to first look at the financial state of account in order to determine where the individual should obtain healthcare.

Funding The author declares not to have any special funding for the production of this work.

Availability of Data and Material All data and material is available.

Code Availability Not applicable.

\section{Declarations}

Conflict of Interest The author declares no conflicting or competing interests.

Ethical Approval This work complies with ethical standards.

Consent to Participate Not applicable.

Consent for Publication I give my consent for publication.

Open Access This article is licensed under a Creative Commons Attribution 4.0 International License, which permits use, sharing, adaptation, distribution and reproduction in any medium or format, as long as you give appropriate credit to the original author(s) and the source, provide a link to the Creative Commons licence, and indicate if changes were made. The images or other third party material in this article are included in the article's Creative Commons licence, unless indicated otherwise in a credit line to the material. If material is not included in the article's Creative Commons licence and your intended use is not permitted by statutory regulation or exceeds the permitted use, you will need to obtain permission directly from the copyright holder. To view a copy of this licence, visit http://creativecommons.org/licen ses/by/4.0/.

\section{References}

\section{Books, Chapters in Books, Journal Articles}

Aravena P, Inostroza M (2015) ¿Salud Pública o Privada? Los factores más importantes al evaluar el sistema de salud en Chile. Rev Med Chile 143:244-251

Arenas Catalán E (2021a) Derecho a la salud en la Nueva Constitución Chilena: Libertad, Solidaridad e Instituciones. In: Asociación Chilena de Derecho Constitucional (eds), Tránsito Constitucional: Hacia una Nueva Constitución. Tirant Lo Blanch, pp 211-231

Arenas Catalán E (2021b) The Human Right to Health: Solidarity in the Era of Healthcare Commercialization. Edward Elgar, Cheltenham

Atria F (2013a) La Constitución tramposa. Lom, Santiago de Chile

Atria F (2013b) Veinte Años Después: Neoliberalismo con Rostro Humano. 2nd ed. Catalonia, Santiago de Chile

Atria F (2014) Derechos sociales y educación: un nuevo paradigma de lo público. Lom, Santiago de Chile

Atria F (2015) Social rights, social contract, socialism. Soc Leg Stud 24(4):598-613. https://doi.org/10. $1177 / 0964663915617860 \mathrm{a}$

Atria F (2016) La Forma del Derecho. Marcial Pons, Madrid 
Atria F et al (2014) El otro modelo: del orden neoliberal al régimen de lo público, 4th edn. Debate, Santiago de Chile

Bassa Mercado J, Aste Leiva B (2015) Mutación en los criterios jurisprudenciales de protección de los derechos a la salud y al trabajo en Chile. Revista Chilena De Derecho 42(1):215-244

Bossert T, Villalobos Dintrans P (2020) Health reform in the Midst of a Social and Political Crisis in Chile, 2019-2020. Health Syst Reform 6(1):1-10

Braveman P, Gruskin S (2003) Defining equity in health. J Epidemiol Community Health 57(4):254-258. https://doi.org/10.1136/jech.57.4.254

Byrne I (2009) Enforcing the right to health: innovative lessons from domestic courts. In: Robinson M, Clapham A (eds) Realizing the human right to health. Zurich, Rüffer and Rub, pp 525-557

Cohen G, Otsuka M (2011) On the currency of egalitarian justice, and other essays on political philosophy. Princeton University Press, New Jersey

Cristi R, Ruiz-Tagle P (2006) La república en Chile. Teoría y práctica del constitucionalismo republicano, 1st edn. Lom, Santiago de Chile

Dixon R, Verdugo S (2021) Los derechos sociales y la reforma constitucional en Chile: hacia una implementación híbrida, legislativa y judicial. Estudios Públicos 162:31-73

Esping Andersen G (1990) The three worlds of welfare capitalism. Polity Press, Cambridge

Garcés M (2020) Estallido social y una Nueva Constitución para Chile. Lom, Santiago de Chile

García Manrique R (2013) La Libertad de todos: una defensa de los derechos sociales. El Viejo Topo, Barcelona

Jordán T (2013) El cambio del eje referenciador del derecho a la protección de la salud a partir de la jurisprudencia constitucional sobre el sub-sistema privado de salud. Estudios Constitucionales 11(1):333-380

Marshall TH (1950) Citizenship and social class and other essays. Cambridge University Press, Cambridge

Mayol A (2012) El derrumbe del modelo: la crisis de la economía de mercado en el Chile contemporáneo. Lom, Santiago de Chile

Salgado C (2015) Derechos sociales, protección de la salud e interpretación constitucional. Revista De Derecho Universidad Católica Del Norte 22(1):401-432

Sánchez Bustos S (2013) Algunas Ideas Fundantes En El Sistema de Salud Chileno. Rev Chil Salud Pública 17(3):224-233

Urriola Urbina R et al (2009) Historia de la Protección Social de la Salud en Chile. Lom, Santiago de Chile

\section{International materials}

United Nations General Assembly, UNGA (1948) Universal Declaration of Human Rights, 10 Dec 1948, 217 A (III)

United Nations General Assembly, UNGA (1966) International Covenant on Economic, Social and Cultural Rights (adopted 16 Dec 1966) 993 UNTS 3

United Nations Committee on Economic, Social and Cultural Rights, UNCESCR (1990) 'General Comment 3: The Nature of States Parties' Obligations (Art 2, Para. 1, of the Covenant)', UN Doc E/1991/23, 14 Dec 1990

United Nations Committee on Economic, Social and Cultural Rights, UNCESCR (2000) General Comment 14 The Right to the Highest Attainable Standard of Health, UN Doc E/C.12/2004/4, 11 May 2000

United Nations Committee on Economic, Social and Cultural Rights, UNCESCR (2006) 'Consideration of Reports Submitted by States Parties Under Articles 16 and 17 of the Covenant: Uzbekistan', UN Doc E/C.12/UZB/CO/1, 24 Jan 2006

United Nations Committee on Economic, Social and Cultural Rights, UNCESCR (2008) 'Consideration of Reports Submitted by States Parties Under Articles 16 and 17 of the Covenant: Hungary' UN Doc E/C.12/HUN/CO/3, 16 Jan 2008

United Nations Committee on Economic, Social and Cultural Rights, UNCESCR (2010) 'Concluding observations of the Committee on Economic, Social and Cultural Rights: The Kingdom of the Netherlands', UN Doc E/C.12/NDL/CO/4-5, 9 Dec 2010 
United Nations Committee on Economic, Social and Cultural Rights, UNCESCR (2014a) 'Concluding observations on the sixth periodic report of Ukraine' UN Doc E/C.12/UKR/CO/6, 13 June 2014

United Nations Committee on Economic, Social and Cultural Rights, UNCESCR (2014b) 'Concluding observations on the third periodic report of Guatemala', UN Doc E/C.12/GTM/CO/3, 9 Dec 2014

United Nations Committee on Economic, Social and Cultural Rights, UNCESCR (2015) 'Concluding observations on the combined second and third periodic reports of Tajikistan', UN Doc E/C.12/TJK/ $\mathrm{CO} / 2-3,25$ Mar 2015

United Nations Committee on Economic, Social and Cultural Rights, UNCESCR (2016) 'Concluding observations on the combined second to fourth periodic reports of the former Yugoslav Republic of Macedonia', UN Doc E/C.12/MKD/CO/2-4, 15 July 2016

United Nations Committee on Economic, Social and Cultural Rights, UNCESCR (2018) 'Concluding observations on the initial report of South Africa', UN Doc E/C.12/ZAF/CO/1, 29 Nov 2018

World Health Organization, WHO (1978) 'Primary Health Care: Report of the International Conference on Primary Health Care, Alma-Ata, USSR' (6-12 Sep 1978)

\section{Reports}

Biblioteca del Congreso Nacional de Chile. Historia de la Ley 10,383. https://obtienearchivo.bcn.cl/obtie nearchivo?id=recursoslegales/10221.3/37249/1/HL10383Art62ServicioNacSalud.pdf Accessed 17 Sep 2021

Facultad de Derecho Universidad Diego Portales (2003) Informe Anual sobre Derechos Humanos en Chile 2003: Hechos de 2002. https://derechoshumanos.udp.cl/informe-anual/informe-anual-sobrederechos-humanos-en-chile-2003/. Accessed 17 Sep 2021

Durán G, Kremerman M (2020) Quiénes ganan el Salario Mínimo en Chile? Evidencia desde la última encuesta CASEN. Fundación Sol, Santiago de Chile

Organización Panamericana de la Salud and Organización Mundial de la Salud (2017) Edición del 2017. Salud en las Americas+: Resumen. Panorama regional y perfiles de país. Organización Panamericana de la Salud, Washington DC

Oxfam (2014) Even it up: time to end extreme inequality. Oxfam International, Oxford

World Bank (2016) Poverty and shared prosperity 2016: taking on inequality. World Bank, Washington DC

WHO (2016a) Domestic private health expenditure (PVT-D) per capita in PPP int\$. The Global Health Observatory, https://www.who.int/data/gho/data/indicators/indicator-details/GHO/domestic-privatehealth-expenditure-(pvt-d)-per-capita-in-ppp-int. Accessed 17 Sep 2021

WHO (2016b) Life expectancy at birth (years). The Global Health Observatory, https://www.who.int/ data/gho/data/indicators/indicator-details/GHO/life-expectancy-at-birth-(years). Accessed 17 Sep 2021

\section{Case law}

Tribunal Constitucional de Chile (2010) Proceso de inconstitucionalidad iniciado de oficio por el Tribunal Constitucional con relación al artículo 38 ter de la Ley 18,933. Rol N ${ }^{\circ} 1710-2010,, 6$ de Agosto de 2010, https://www.tribunalconstitucional.cl/expedientes?rol=1710-10. Accessed 17 Sep 2021

Tribunal Constitucional Portugal (1984) Acórdão do Tribunal Constitucional N 39/84, en "Acórdãos do Tribunal Constitucional”, 11 April 1984, $3^{\circ}$ Vol 95ff

\section{Chile's legal instruments}

Actas Oficiales de la Comisión Constituyente Session 190. 17 March 1976, https://www.bcn.cl/leychile/ constituciones

Actas Oficiales de la Comisión Constituyente Session 192. 23 March 1976, https://www.bcn.cl/leychile/ constituciones 
Actas Oficiales de la Comisión Constituyente Session 205. 28 Abril 1976, https://www.bcn.cl/leychile/ constituciones

Constitución Política de la República de Chile (1925) 18 de septiembre de 1925, https://www.bcn.cl/ leychile/navegar?idNorma=241203. Accessed 17 Sep 2021

Constitución Política de la República de Chile (1980) 11 de agosto de 1980, https://www.bcn.cl/leychile/ navegar?idNorma=242302. Accessed 17 Sep 2021

Ley de Reforma Constitucional (1971) N 17,398, 9 de enero de 1971, https://www.bcn.cl/leychile/naveg ar?idNorma=28981. Accessed 17 Sep 2021

Ministerio de Defensa Nacional (1975) Decreto Ley 844, 6 de Enero de 1975, https://www.bcn.cl/leych ile/navegar?idNorma=6627. Accessed 17 Sep 2021

Ministerio de Defensa Nacional (1996) Ley 19,465, 2 Agosto de 1996, https://www.bcn.cl/leychile/naveg ar?idNorma=30832. Accessed 17 Sep 2021

Ministerio del Interior (1988) Ley 18,700 Orgánica Constitucional Sobre Votaciones Populares y Escrutinios, 6 de Mayo de 1988, http://www.leychile.cl/N?i=30082\&t=0. Accessed 17 Sep 2021

Ministerio del Interior y Seguridad Pública (2015) Ley 20,840, 5 de Mayo de 2015, http://www.leychile. $\mathrm{cl} / \mathrm{N} ? \mathrm{i}=1077039 \& \mathrm{f}=2015-05-05$. Accessed 17 Sep 2021

Ministerio de Salud (2005) Decreto con Fuerza de Ley $\mathrm{N}^{\circ}$ 1, de 23 de Septiembre de 2005, https://www. bcn.cl/leychile/navegar?idNorma=249177\&idParte=\&idVersion=2006-04-24. Accessed 17 Sep 2021

Superintendencia de Salud, Enfermedades Garantizadas AUGE-GES. http://www.supersalud.gob.cl/difus ion/665/w3-propertyvalue-1962.html. Accessed 17 Sep 2021

\section{News}

CIPER (2019) Por un Nuevo Pacto Social en Salud para Chile, https://www.ciperchile.cl/2019/11/30/porun-nuevo-pacto-social-en-salud-para-chile/. Accessed 17 Sep 2021

CIPER (2020) Para que nunca más en Chile: hacia una salud y vida digna para todos y todas, https:// www.ciperchile.cl/2020/04/15/para-que-nunca-mas-en-chile-hacia-una-salud-y-vida-digna-paratodos-y-todas/. Accessed 17 Sep 2021

Pereyra González (2019) El sistema de salud de Chile es uno de los grandes reclamos de la población. A Diaria, https://ladiaria.com.uy/opinion/articulo/2019/11/el-sistema-de-salud-de-chile-es-uno-de-losgrandes-reclamos-de-la-poblacion/ Accessed 17 Sep 2021

Senado de Chile (2019) Logran histórico acuerdo para Nueva Constitución: participación ciudadana será clave, https://www.senado.cl/logran-historico-acuerdo-para-nueva-constitucion-participacion/ senado/2019-11-14/134609.html. Accessed 17 Sep 2021

Servicio Electoral de Chile (2020) Plebiscito Nacional 2020 fue la mayor votación de la historia de Chile, https://www.plebiscitonacional2020.cl/plebiscito-nacional-2020-fue-la-mayor-votacion-de-la-histo ria-de-chile/. Accessed 17 Sep 2021

Publisher's Note Springer Nature remains neutral with regard to jurisdictional claims in published maps and institutional affiliations. 